\title{
Author Correction: Scutoids are a geometrical solution to three-dimensional packing of epithelia
}

\author{
Pedro Gómez-Gálvez (10) 1, Pablo Vicente-Munuera (10 1, Antonio Tagua ${ }^{1}$, Cristina Forja ${ }^{1}$, Ana M. Castro ${ }^{1}$, \\ Marta Letrán', Andrea Valencia-Expósito (1) 2 , Clara Grima (10 3 , Marina Bermúdez-Gallardo1, \\ Óscar Serrano-Pérez-Higueras ${ }^{1}$, Florencia Cavodeassi ${ }^{4,5}$, Sol Sotillos (1D ${ }^{2}$, María D. Martín-Bermudo (i) ${ }^{2}$, \\ Alberto Márquez (10 ${ }^{3}$, Javier Buceta ${ }^{6,7} \&$ Luis M. Escudero (i) ${ }^{1}$
}

Correction to: Nature Communications https://doi.org/10.1038/s41467-018-05376-1; published online: 27 July 2018

The original version of this article contained an error in ref. 39, which incorrectly cited 'Fristrom, D. \& Fristrom, J. W. in The Development of Drosophila melanogaster (eds. Bate, M. \& Martinez-Arias, A.) II, (Cold spring harbor laboratory press, 1993)'. The correct reference is 'Condic, M.L, Fristrom, D. \& Fristrom, J.W. Apical cell shape changes during Drosophila imaginal leg disc elongation: a novel morphogenetic mechanism. Development 111: 23-33 (1991)'. Furthermore, the last sentence of the fourth paragraph of the introduction incorrectly omitted citation of work by Rupprecht et al. The correct citation is given below. These errors have now been corrected in both the PDF and HTML version of this article.

Rupprecht, J.F., et al. Geometric constraints alter cell arrangements within curved epithelial tissues. Mol. Biol. Cell 28, 3582-3594 (2017).

Published online: 08 October 2018

(2) Open Access This article is licensed under a Creative Commons Attribution 4.0 International License, which permits use, sharing, adaptation, distribution and reproduction in any medium or format, as long as you give appropriate credit to the original author(s) and the source, provide a link to the Creative Commons license, and indicate if changes were made. The images or other third party material in this article are included in the article's Creative Commons license, unless indicated otherwise in a credit line to the material. If material is not included in the article's Creative Commons license and your intended use is not permitted by statutory regulation or exceeds the permitted use, you will need to obtain permission directly from the copyright holder. To view a copy of this license, visit http://creativecommons.org/licenses/by/4.0/.

(C) The Author(s) 2018

\footnotetext{
${ }^{1}$ Departamento de Biología Celular, Universidad de Sevilla and Instituto de Biomedicina de Sevilla (IBiS), Hospital Universitario Virgen del Rocío/CSIC/ Universidad de Sevilla, 41013 Seville, Spain. ${ }^{2}$ CABD, CSIC/JA/UPO, Campus Universidad Pablo de Olavide, 41013 Seville, Spain. ${ }^{3}$ Departamento de Matemática Aplicada I, Universidad de Sevilla, 41012 Seville, Spain. ${ }^{4}$ Centro de Biología Molecular Severo Ochoa and CIBER de Enfermedades Raras, C/ Nicolás Cabrera 1, 28049 Madrid, Spain. ${ }^{5}$ St. George's, University of London, Cranmer Terrace, London SW17 ORE, UK. ${ }^{6}$ Bioengineering Department, Lehigh University, Bethlehem, PA 18018, USA. ${ }^{7}$ Chemical and Biomolecular Engineering Department, Lehigh University, Bethlehem, PA 18018, USA. Correspondence and requests for materials should be addressed to J.B. (email: jbuceta@lehigh.edu) or to L.M.E. (email: Imescudero-ibis@us.es)
} 